\title{
Correction to: Beta alanine supplementation effects on metabolic contribution and swimming performance
}

\author{
Matheus Silva Norberto ${ }^{1,2^{*}}$, Ricardo Augusto Barbieri ${ }^{2,3}$, Danilo Rodrigues Bertucci ${ }^{4}$, Ronaldo Bucken Gobbi ${ }^{2}$, \\ Eduardo Zapaterra Campos ${ }^{5}$, Alessandro Moura Zagatto ${ }^{6}$, Ellen Cristini De Freitas ${ }^{2}$ and Marcelo Papoti ${ }^{1,2}$
}

\section{Correction to: J Int Soc Sports Nutr 17, 40 (2020) https://doi.org/10.1186/s12970-020-00365-6}

The original article contains a typo in co-author, Alessandro Moura Zagatto's name. The correct presentation can be viewed in this Correction article.

\begin{abstract}
Author details
${ }^{1}$ University of São Paulo, Medicine University of Ribeirão Preto (FMRP-USP), Ribeirão Preto, São Paulo, Brazil. ${ }^{2}$ University of São Paulo, School of Physical Education and sport of Ribeirão Preto (EEFERP-USP), Ribeirão Preto, São Paulo, Brazil. ${ }^{3}$ Estácio University, Ribeirão Preto, São Paulo, Brazil. ${ }^{4}$ Department of Physical Education, State São Paulo University, (UNESP), Rio Claro, São Paulo, Brazil. ${ }^{5}$ Department of Physical Education, Federal University of Pernambuco, (UFPE), Recife, Pernambuco, Brazil. ' ${ }^{6}$ epartment of Physical Education, State São Paulo University, (UNESP), Bauru, São Paulo, Brazil.
\end{abstract}

Published online: 08 October 2020

\section{Reference}

1. Silva Norberto M, et al. Beta alanine supplementation effects on metabolic contribution and swimming performance. J Int Soc Sports Nutr. 2020;17:40. https://doi.org/10.1186/s12970-020-00365-6.

The original article can be found online at https://doi.org/10.1186/s12970020-00365-6.

* Correspondence: matheus.norberto@usp.br

'University of São Paulo, Medicine University of Ribeirão Preto (FMRP-USP), Ribeirão Preto, São Paulo, Brazil

${ }^{2}$ University of São Paulo, School of Physical Education and sport of Ribeirão Preto (EEFERP-USP), Ribeirão Preto, São Paulo, Brazil

Full list of author information is available at the end of the article

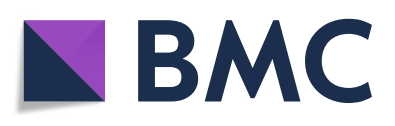

(c) The Author(s). 2020, corrected publication March 2021. Open Access This article is licensed under a Creative Commons Attribution 4.0 International License, which permits use, sharing, adaptation, distribution and reproduction in any medium or format, as long as you give appropriate credit to the original author(s) and the source, provide a link to the Creative Commons licence, and indicate if changes were made. The images or other third party material in this article are included in the article's Creative Commons licence, unless indicated otherwise in a credit line to the material. If material is not included in the article's Creative Commons licence and your intended use is not permitted by statutory regulation or exceeds the permitted use, you will need to obtain permission directly from the copyright holder. To view a copy of this licence, visit http://creativecommons.org/licenses/by/4.0/. The Creative Commons Public Domain Dedication waiver (http:// creativecommons.org/publicdomain/zero/1.0/) applies to the data made available in this article, unless otherwise stated in a credit line to the data. 